\title{
PENGEMBANGAN APLIKASI MOBILE LEARNING FISIKA SEBAGAI MEDIA PEMBELAJARAN PENDUKUNG
}

\section{PHYSICS MOBILE LEARNING APLICATION DEVELOPMENT AS A SUPPORTING INSTRUCTIONAL MEDIA}

\author{
Indra Gunawan, M.T. \\ Prodi Pendidikan Fisika, Fakultas Tarbiyah dan Keguruan, \\ IAIN Raden Intan Lampung, Email: indra_6una1@yahoo.co.id
}

\begin{abstract}
The objective of this research is to create a supporting instructional media in the form of mobile learning of main material for Senior Secondary School students. The created mobile learning was played on mobile phone that supports flash player, mainly Symbian $5603^{\text {rd }}$ based mobile phone. The method applied in this research was research and development. The first step was limited on material of heat transfer. The trial of application was conducted to 2 specialized lecturers, 2 media experts, 2 Physics teachers of Senior Secondary School, and 44 students of AlAzhar Senior Secondary School, Bandar Lampung. Indicators used to assess the created instructional media were appropriateness of the content to the purpose, appropriateness of instruction to the technical quality. Marks of the three indicators were above $80 \%$, so that the created mobile learning was categorized as very good. Based on the findings, it may be concluded that the instructional media in the form of mobile learning can be used as a supporting instructional media for Senior Secondary School students to learn Physics subject.
\end{abstract}

Keywords: instructional media, mobile learning, heat transfer, physic subject, and Senior Secondary School.

\begin{abstract}
Abstrak: Penelitian ini bertujuan untuk menghasilkan media pembelajaran pendukung berbentuk mobile learning pada materi esensial untuk siswa SMA. Mobile learning yang dibuat dijalankan pada handphone yang mendukung flash player terutama berbasis symbian S60 3rd. Metode yang digunakan dalam penelitian ini, yaitu metode penelitian dan pengembangan (Research and Development). Tahap pertama dibatasi pada materi perpindahan kalor. Uji coba aplikasi dilakukan kepada 2 orang dosen ahli materi dan 2 orang ahli media, dan 2 guru fisika SMA, serta 44 siswa SMA Al-Azhar Bandar Lampung. Indikator yang digunakan untuk menilai media pembelajaran yang dibuat, yaitu kesesuaian isi dan tujuan, kesesuaian pembelajaran dan kualitas teknis . Nilai dari ketiga indikator berada di atas $80 \%$, sehingga mobile learning yang dibuat dikategorikan sangat baik. Berdasarkan hasil penelitian, dapat disimpulkan bahwa media pembelajaran berbentuk mobile learning dapat dijadikan sebagai media pembelajaran pendukung pada pelajaran Fisika untuk siswa SMA.
\end{abstract}

Kata kunci: media pembelajaran, mobile learning, perpindahan kalor, Fisika, dan SMA

\section{Pendahuluan}

Fisika adalah salah satu cabang ilmu pengetahuan alam yang mempelajari fenomena alam, baik secara kualitatif maupun secara kuantitatif (Supriyati, 2007). Fisika juga merupakan ilmu pengetahuan paling fundamental, karena merupakan dasar dari semua bidang sains yang lain (Tipler, alih bahasa Lea Prasetio, Rahmad W. Adi, 1998). Materi mata pelajaran fisika terdiri dari teori, hukum-hukum, postulat-postulat dan rumus-rumus yang sulit untuk diingat. Hasil survey awal pada 49 siswa SMA AlAzhar menunjukkan 88\% siswa mengalami kesulitan dalam mempelajari Fisika. Kondisi ini memperkuat bahwa pelajaran Fisika merupakan pelajaran yang sulit dan yang ingin dihindari oleh siswa. Permasalahan ini terjadi dikarenakan oleh beberapa faktor, yaitu: 1) adanya gambaran pada siswa bahwa Fisika merupakan pelajaran sulit serta 
penuh dengan rumus-rumus; 2) banyaknya materi pelajaran yang harus dihafalkan; 3) kurangnya motivasi dari dalam diri siswa untuk mempelajari Fisika; dan 4) ketidaktepatan model, metode, dan media pembelajaran yang digunakan oleh guru, sehingga kegiatan pembelajaran terasa jenuh dan membosankan. Masalah ini dapat diatasi dengan cara memperhatikan komponen-komponen dalam sistem pembelajaran, salah satunya yaitu media pembelajaran.

Media pembelajaran memiliki peran yang sangat penting dalam mencapai tujuan dari pembelajaran. Hal ini disebabkan media merupakan alat yang digunakan untuk menyampaikan isi dari pembelajaran. Daryanto (2010) menyatakan bahwa penggunaan media pembelajaran dapat mengatasi keterbatasan ruang, waktu tenaga dan daya indra, selain itu media pembelajaran dapat menimbulkan gairah belajar. Pengembangan media pembelajaran diperlukan untuk mampu mengatasi masalahmasalah dalam proses belajar, salah satu bentuk dari pen gemb anga $n$ me dia pemb elaj ar an ada lah pemanfaatan teknologi informasi dan komunikasi (TIK). Bentuk dari pemanfaatan teknologi informasi dan komunikasi dalam dunia pendidikan, yaitu electronic learning (e-learning). Masalah dalam proses belajar, seperti waktu belajar yang singkat, sedikitnya alat-alat laboratorium, atau jauhnya peserta didik ke pusat sumber belajar mampu diatasi dengan hadirnya $e$-learning.

Mobile learning (m-learning) adalah salah satu bagian dari e-learning. M-learning merupakan media pembelajaran yang menggunakan perangkat untuk menj alankannya. Per angkat tersebut ber upa handphone, PDA dan tablet PC. Dengan adanya mobile learning tersebut, proses belajar mengajar akan lebih efektif. Siswa dapat mengakses materi pelajaran dari mana saja tanpa dibatasi oleh ruang dan tempat serta memiliki fleksibilitas, karena tidak terkait dengan waktu.

Berdasarkan uraian di atas, permasalahan dalam penelitian ini, yaitu "Apakah aplikasi mobile learning Fisika dengan menggunakan adobe flash dapat dijadikan sebagai media pembelajaran pendukung pada materi perpindahan kalor di SMA?".

Tujuan penelitian ini yakni menghasilkan media pembelajaran pendukung berbentuk mobile learning pada materi esensial, khususnya tahap pertama perpindahan kalor untuk siswa SMA.

\section{Kajian Teori}

\section{Media Pendidikan}

Menurut Sadiman (2010) media pendidikan adalah segala sesuatu yang dapat digunakan untuk menyalurkan pesan dari pengirim ke penerima, sehingga dapat merangsang pikiran, perasaan, perhatian $\mathrm{d}$ an $\mathrm{m}$ inat serta perhatian siswa sedemikian rupa sehingga proses belajar terjadi. Menurut Gagne (1970) (dalam Sadiman, 2010) media adalah berbagai jenis komponen dalam lingkungan siswa yang dapat merangsangnya untuk belajar. Menurut Syaiful Bahri Djamarah dan Asawan Zain (2002), media adalah alat bantu apa saja yang dapat dijadikan sebagai penyalur pesan guna mencapai tujuan pengajaran.

Dari beberapa definisi di atas, dapat dikatakan bahwa media pendidikan adalah segala $\mathrm{j}$ enis komponen dalam lingkungan siswa yang dapat merangsang pikiran, perasaan, minat serta perhatian siswa, sehingga proses belajar terjadi dan pesan pembelajaran tersampaikan dengan baik.

Secara umum, kedudukan media pembelajaran menurut Kustandi, Cecep dan Bambang Sutjipto (2011) adalah sebagai: 1) alat bantu; 2) alat penyalur pesan; 3) alat penguatan (reinforcement); dan 4) wakil guru dalam menyampaikan informasi secara lebih teliti, jelas, dan menarik.

Adapun manfaat yang didapatkan dari penggunaan media pendidikan menurut Daryanto (2010), yaitu: 1) memperjelas pesan agar tidak terlalu verbalistis; 2) mengatasi keterbatasan ruang, waktu tenaga dan daya indra; 3) menimbulkan gairah belajar, interaksi lebih langsung antarmurid dengan sumber belajar; 4) memungkinkan anak belajar mandiri sesuai dengan bakat dan kemampuan visual, auditori dan kinestetiknya; 5) memberi rangsangan yang sama, mempersamakan pengalaman dan menimbulkan persepsi yang sama.

Konstribusi media pembelajaran menurut Daryanto (2010), yaitu: 1) penyampaian pesan pembelajaran dapat lebih terstandar; 2) pembelajaran dapat lebih menarik; 3) pembelajaran menjadi lebih interaktif dengan menerapkan teori belajar; 4) waktu pelaksanaan pembelajaran dapat diperpendek; 5) kualitas pembelajaran dapat ditingkatkan; 6) proses pembelajaran dapat berlangsung kapanpun dan di manapun; 7) sikap positif siswa terhadap materi pembelajaran serta proses pembelajaran dapat ditingkatkan; dan 8) peran guru berubah ke arah yang positif. 


\section{Mobile Learning}

Menurut Tamimuddin (2010), bahwa istilah mobile learning diartikan kepada penggunaan perangkat teknologi informasi (TI) genggam dan bergerak, seperti PDA, handphone, laptop dan tablet PC, dalam pengajaran dan pembelajaran.

Menurut Quinn Clark (2000) "Learning is the intersection of mobile computing and elearning: accessible resources wherever you are, strong search capabilities, rich interaction, powerful support for effective learning, and performance based assessment. e-learning independent of location in time or space.". learners and mobility of learning".

Dari beberapa pendapat di atas, dapat didefinisikan bahwa mobile learning merupakan media pembelajaran dengan menggunakan perangkat bergerak seperti handphone, PDA serta tablet PC, sehingga menawarkan kemudahan dalam mengakses materi pembelajaran dari mana saja dan kapan saja. Perlu disadari juga bahwa mobile learning adalah salah satu kemajuan dalam pengembangan teknologi informasi dan komunikasi (TIK). Mobile learning juga adalah bagian dari electronic learning hal ini sesuai dengan skema yang diberikan oleh Tamimuddin (2010), yaitu sebagai berikut:

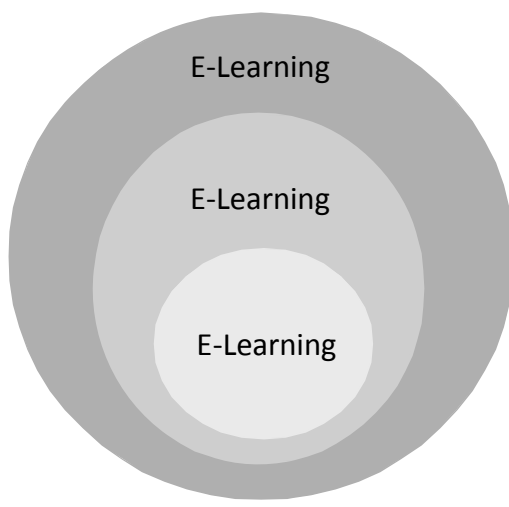

\section{Gambar 1. Skema Posisi Mobile Learning}

Pada pelaksanaan pembelajaran di kelas mobile learning memiliki tiga fungsi seperti yang diutarakan Hasan (2010), ketiga fungsi tersebut, yakni supplement (tambahan), complement (pelengkap) dan substitusi (pengganti).

Mobile learning sebagai supplement (tambahan), memiliki pengertian bahwa terdapat kebebasan pada siswa untuk memilih dan memanfaatkan mobile learning sebagai media pembelajaran, sehingga tidak ada paksaan atau kewajiban untuk mengakses materi pelajaran melalui mobile learning.

Mobile learning dapat menjadi complement (pelengkap) dari materi pelajaran yang diberikan di kelas. Sebagai pelengkap, mobile learning dapat berfungsi sebagai penguat (reinforcement) atau remedial dan pengayaan (enrichment).

Mobile learning sebagai pengganti, artinya siswa diberi kebebasan untuk memilih menggunakan model pembelajaran yang mereka inginkan. Terdapat 3 pilihan, yaitu: 1) sepenuhnya menggunakan model pembelajaran konvensional; 2) sebagian menggunakan pembelajaran konvensional dan seba- giannya menggunakan teknologi; dan 3) sepenuhnya menggunakan teknologi.

Menurut catatan yang dikeluarkan Asosiasi Telepon Seluler Indonesia (ATSI) pada tahun 2013, ada sekitar 195 juta penduduk Indonesia menjadi pelanggan layanan seluler sehingga diprediksi 60\% penduduk Indonesia sudah memiliki telepon selular. Selain itu, hasil survai awal terhadap 49 siswa AlAzhar menunjukkan $100 \%$ siswa memiliki handphone. Demikian pula di SMAN 2 Bandar Lampung, hampir $100 \%$ siswa memiliki handphone. Data ini menunjukkan bahwa terdapat peluang yang besar terhadap perkembangan penggunaan mobile learning. Saat ini ada dua lembaga di Indonesia yang telah mengeluarkan perangkat mobile learning dan didistr ibusikan secar a grat is. Pert ama, Pusat Pengembangan dan Pemberdayaan Pendidik dan Tenaga Kependidikan (P4TK) Matematika, Kementerian Pendidikan dan Kebudayaan dengan produk mobile learning pada mata pelajaran Matematika dan platform yang digunakan, yaitu Java. Kedua adalah Balai Pengembangan Multimedia Semarang dengan produk mobile learning untuk pelajaran Fisika, Matematika, Kimia dan Biologi. Untuk mata pelajaran Fisika hanya ada 14 koleksi.

Dengan adanya kemudahan dan peluang yang besar terhadap pengembangan aplikasi mobile learning untuk pelajaran Fisika, maka dapat dibuat aplikasi mobile learning Fisika. Aplikasi mobile learning yang dibuat menggunakan flat form flash lite 2.x dengan materi perpindahan kalor untuk siswa SMA tahap pertama dan selanjutnya akan dikembangkan untuk materi esensial lain. Jenis handphone yang dapat menjalankan program aplikasi ini adalah handphone yang mendukung untuk menjalankan program flash lite player terutama yang berbasis symbian S60 30rd. 


\section{Metodologi Penelitian}

Metode penelitian yang digunakan adalah metode penelitian dan pengembangan (research and development). Metode penelitian ini digunakan untuk menghasilkan produk tertentu, dan menguji keefektifan produk tersebut (Sugiyono, 2010).

\section{Tempat dan Waktu Penelitian}

Penelitian ini dilakukan di Laboratorium Pendidikan Fisika IAIN Raden Intan Lampung dan SMA AlAzhar Bandar Lampung. Pelaksanaan penelitian dilakukan mulai bulan Januari 2014 s.d Maret 2014.

\section{Sampel Penelitian}

Penelitian ini melibatkan 2 dosen ahli materi, 2 dosen ahli media, 2 guru fisika dan sample melibatkan 44 siswa kelas X SMA Al-Azhar Bandar Lampung.

\section{Instrumen Penelitian}

Instrumen penelitian berupa kuesioner untuk ahli media, ahli materi, guru dan siswa. Instrumen penelitian diberikan kepada ahli media, ahli materi, guru dan siswa SMA. Instrumen berisikan evaluasi terhadap kelayakan produk yang dihasilkan. Kriteria penilaian untuk uji ahli materi terdiri dari kesesuaian isi dan tujuan serta kesesuaian pembelajaran. Kriteria untuk uji ahli media dan uji coba pada guru fisika sekolah terdiri dari kesesuaian isi dan tujuan, kesesuaian pembelajaran serta kualitas teknis (desain). Uji coba produk pada siswa berupa angket yang berisi tanggapan terhadap media mobile learning perpindahan kalor. Untuk melakukan penilaian terhadap instrumen yang diberikan kepada ahli media, ahli materi, guru dan siswa dalam pembuatan media pembelajaran mobile learning menggunakan skala Likert.

\section{Prosedur Penelitian}

Prosedur dalam penelitian aplikasi mobile learning mengacu pada langkah-langkah penelitian dan pengembangan dari Gall dan Borg (1989) (dalam Sukmandinata, 2008), yaitu: 1) penelitian dan pengumpulan data (research and informat ion collecting); 2) perencanaan pengembangan produk; 3) pengembangan produk awal; 4) uji coba produk awal; 5) penyempurnaan produk awal; 6) uji coba produk yang telah disempurnakan; 7) penyempurnaan produk dan pengujian produk; 8) produk akhir dan implementasi-institusionalisasi produk.

\section{Hasil dan Bahasan}

Mobile learning yang dikembangkan memuat materi esensial tentang perpindahan kalor. Materi ini ditampilkan, karena belum ada produk mobile learning yang membahas. Selain itu, dalam materi ini diperlukan animasi-animasi yang dapat membantu siswa lebih mudah memahaminya. Pengembangan produk mobile learning ini dikuatkan oleh hasil kuesioner yang menyatakan bahwa $80 \%$ siswa mendukung untuk dibuatnya mobile learning dengan materi perpindahan kalor.

Mobile learning dibuat dengan menggunakan software Adobe Flash dengan spesifikasi sebagai berikut:

- Software: Adobe Flash CS4

-Emulator untuk menjalankan di PC: Adobe DeviceCentral CS4

- Flash version: flash lite $2 . x$

- Dimensi: 240 x 320 pixel

- Type content: standalone player

- Memory setelah dibuat: $620 \mathrm{~kb}$

Tampilan mobile learning perpindahan kalor terdiri dari:

Tampilan layar utama

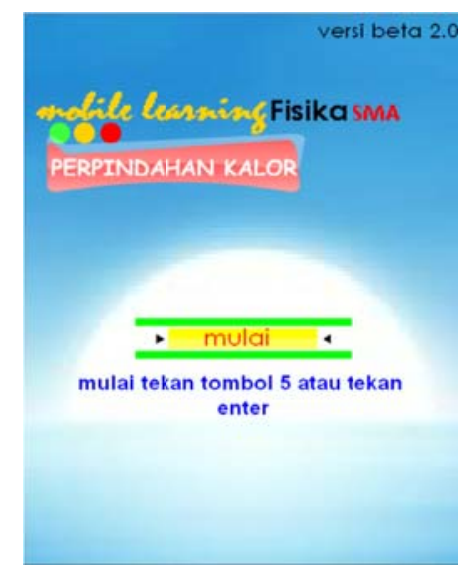

Gambar 3. Layar Utama pada Handphone 
Tampilan layar menu

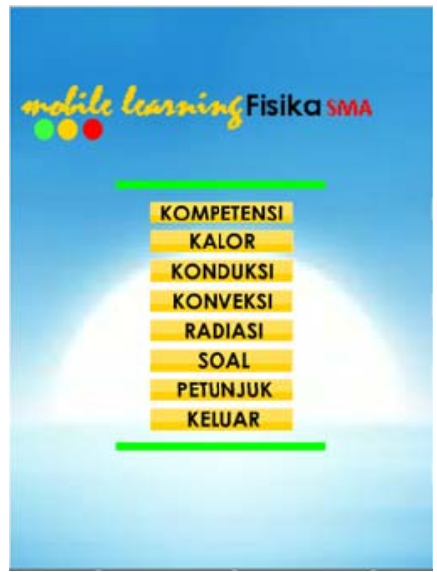

Gambar 4. Layar Menu pada Handphone

Tampilan layar kompetensi

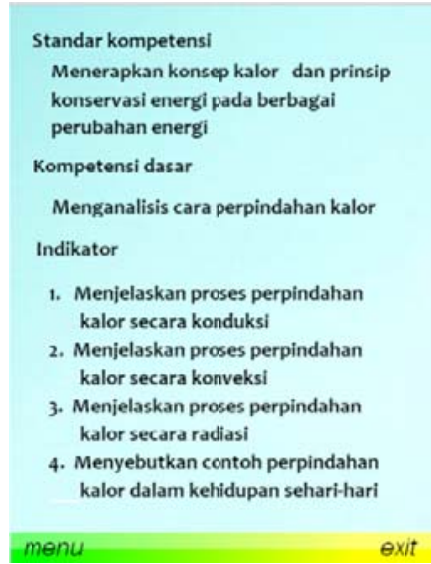

Gambar 5. Layar Kompetensi pada Handphone

Layar petunjuk penggunaan

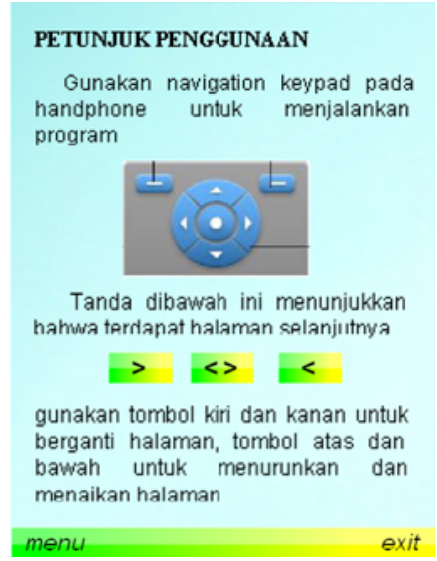

Gambar 6. Tampilan Layar Petunjuk Penggunaan pada Handphone
Media mobile learning diujicobakan kepada ahli materi fisika, ahli media pembelajaran, guru Fisika SMA, dan tanggapan siswa SMA terhadap media yang dibuat. Uji coba kelayakan ini dilakukan untuk mengetahui tingkat kualitas dari media yang dibuat.

\section{Uji Coba (Validitas) oleh Ahli Materi Fisika}

Program mobile learning fisika materi perpindahan kalor diberikan kepada dua dosen untuk diujicobakan. Tempat uji coba dilaksanakan di Jurusan Fisika Universitas Negeri Bandar Lampung. Kuesioner uji ahli materi terdiri dari 18 pertanyaan dengan dua indikator penilaian, yaitu kesesuaian isi dan tujuan, dan kesesuaian pembelajaran. Hasil kuesioner uji ahli materi terhadap mobile learning yang dibuat terdapat pada Tabel 1.

Tabel 1. Hasil Kuesioner Uji Ahli

Materi

\begin{tabular}{|l|l|c|l|}
\hline No. & \multicolumn{1}{|c|}{ Indikator } & $\begin{array}{c}\text { Persentase } \\
\text { rata-rata }\end{array}$ & Keterangan \\
\hline 1. & $\begin{array}{l}\text { Kesesuaian Isi } \\
\text { dan Tujuan }\end{array}$ & $83 \%$ & sangat baik \\
\hline 2. & $\begin{array}{l}\text { Kesesuaian } \\
\text { Pembelajaran }\end{array}$ & $81 \%$ & sangat baik \\
\hline & Total rata-rata & $82 \%$ & sangat baik \\
\hline
\end{tabular}

Dari tabel terlihat nilai rata-rata kuesioner oleh ahli materi berada di atas 80 , itu berarti menurut skala Likert materi yang disajikan dalam mobile learning ini sangat baik, dalam arti materi sudah sesuai dengan kurikulum sekolah.

\section{Uji Coba (Validitas) oleh Ahli Media}

\section{Pembelajaran}

Uji coba (validitas) oleh ahli media pembelajaran dilakukan di Fakultas Ilmu Pendidikan Universitas Negeri Bandar Lampung, dengan melibatkan dua dosen evaluasi media pembelajaran. Kuesioner uji coba terdiri dari 20 pertanyaan yang mencakup tiga indikator, yaitu kesesuaian isi dan tujuan, kesesuaian pembelajaran, dan kualitas teknis (desain).

Hasil kuesioner uji ahli media pembelajaran terhadap mobile learning yang dibuat terdapat pada Tabel 2. 
Tabel 2. Hasil Kuisioner Uji Ahli

Media

\begin{tabular}{|c|l|c|c|}
\hline No. & \multicolumn{1}{|c|}{ Indikator } & $\begin{array}{c}\text { Persentase } \\
\text { rata-rata }\end{array}$ & Keterangan \\
\hline 1. & Kesesuaian isi dan tujuan & $88 \%$ & $\begin{array}{c}\text { sangat } \\
\text { baik }\end{array}$ \\
\hline 2. & Kesesuaian pembelajaran & $79 \%$ & $\begin{array}{c}\text { sangat } \\
\text { baik }\end{array}$ \\
\hline 3. & Teknis (desain) & $82 \%$ & $\begin{array}{c}\text { sangat } \\
\text { baik }\end{array}$ \\
\hline & Rata-rata keseluruhan & $83 \%$ & $\begin{array}{c}\text { sangat } \\
\text { baik }\end{array}$ \\
\hline
\end{tabular}

Dari kriteria tabel skala likert, nilai rata-rata kuesioner oleh ahli media berada di atas 80 sehingga aplikasi mobile learning yang dibuat dalam kategori sangat baik, dalam arti bisa dipakai sebagai media pendukung.

\section{Uji Coba (Validitas) oleh Guru Fisika Sekolah}

Uji coba atau validasi oleh guru Fisika sekolah dilaksanakan di sekolah SMA Al-Azhar 1 Bandar Lampung. Guru yang dilibatkan dalam penelitian ini sebanyak dua guru Fisika. Kuesioner terdiri dari 18 pertanyaan yang memuat tiga indikator, yaitu kesesuaian isi dan tujuan, kesesuaian pembelajaran, serta teknis dan desain.

Adapun hasil dari kuesioner tersebut disajikan pada Tabel 3.

Tabel 3. Hasil Kuesioner Uji Coba pada Guru Sekolah

\begin{tabular}{|r|l|c|c|}
\hline No. & \multicolumn{1}{|c|}{ Indikator } & $\begin{array}{r}\text { Persentase } \\
\text { rata-rata }\end{array}$ & Keterangan \\
\hline 1. & $\begin{array}{l}\text { Kesesuaian isi } \\
\text { dan tujuan }\end{array}$ & $88 \%$ & sangat baik \\
\hline 2. & $\begin{array}{l}\text { Kesesuaian } \\
\text { pembelajaran }\end{array}$ & $79 \%$ & sangat baik \\
\hline 3. & $\begin{array}{l}\text { Teknis (desain) } \\
\text { Rata-rata } \\
\text { keseluruhan }\end{array}$ & $83 \%$ & sangat baik \\
\hline
\end{tabular}

Dari Tabel 3 terlihat nilai rata-rata kuesioner oleh guru Fisika juga berada di atas nilai 80, itu berarti menurut skala Likert isi dan tujuan, kesesuaian pembelajaran, teknis dan desain juga sangat baik.

\section{Responden Sampel Siswa Kelas X}

Tes produk dilakukan pada siswa kelas $\mathrm{X}$ dengan melibatkan dua kelas dengan jumlah responden, yaitu 44 siswa. Siswa diminta untuk mengisi kuesioner yang berisi tanggapan terhadap media mobile learning yang dibuat. Berdasarkan hasil dari kuesioner menunjukkan nilai rata-rata untuk semua pertanyaan sebesar $80 \%$, menandakan bahwa media pembelajaran mobile learning perpindahan kalor memiliki nilai sangat baik.

\section{Simpulan dan Saran}

\section{Simpulan}

Berdasarkan hasil penelitian, dapat disimpulkan bahwa aplikasi mobile learning Fisika dengan menggunakan adobe flash pada materi pelajaran perpindahan kalor khususnya dapat dijadikan sebagai media pembelajaran pendukung untuk siswa SMA. Nilai untuk media pembelajaran yang dibuat, yaitu sangat baik. Hal ini didukung oleh nilai rata-rata kuesioner hasil uji coba terhadap ahli media sebesar $82 \%$, ahli materi sebesar $83 \%$, serta uji coba kepada guru sebesar $83 \%$.

Media pembelajaran ini memiliki kelebihan, yaitu siswa dapat mengakses materi pelajaran dari mana saja tanpa dibatasi oleh ruang dan tempat serta memiliki fleksibilitas, karena tidak terkait dengan waktu.

\section{Saran}

Atas dasar simpulan tersebut para guru disarankan:

1) menggunakan berbagai media pembelajaran dalam mengajar, 2) menggunakan media pembelajaran mobile learning pada materi esensial terkait ujian nasional, sehingga siswa dapat melihat dan mengingat dengan cepat kapan saja karena biasanya HP selalu dibawa, 3) mobile learning juga dapat dijadikan sebagai penyaji materi pengayaan bagi siswa yang cepat atau untuk remedial bagi siswa yang lambat mencapai KKM, 4) mobile learning yang dibuat ini memiliki keterbatasan dalam soal pilihan ganda, option hanya tiga. Untuk itu, peneliti berikutnya dapat mengembangkan program berbeda yang memiliki pilihan minimal 5 sesuai dengan syarat soal evaluasi tingkat siswa SMA. 


\section{Pustaka Acuan}

Daryanto. 2010. Media Pembelajaran. Yogyakarta: Penerbit Gava Media.

Djamarah, Syaiful Bahri dan Aswan Zain. 2002. Strategi Belajar Mengajar. Jakarta: PT. RinekaCipta.

H, Muh. Tamimuddin. 2010. Mengenal Mobile Learning (M-Learning), diunduh 20 Maret 2011 dari mtamim. Files.Wordpress.Com/2008/12/Mlearn_Tam im.Pdf.

Hasan, Miftah. 2010. Implementasi Teori Belajar dalam Desain Sistem Pembelajaran Mobile Learning, diunduh pada 17 Maret 2011 dari http://www.mediapendidikan.net/ index.php?option=com_content $\&$ view $=$ artic le\&id=6:teori-belajar\&catid=29:teoribelajar\&Itemid $=22$

Kustandi, Cecep dan Bambang Sutjipto. 2011. Media Pembelajaran Manual dan Digital. Bogor: Penerbit Ghalia Indonesia.

Quinn, Clark. 2010. Mlearning: Mobile, Wireless, In-Your-Pocket Learning, diunduh pada 26 Maret 2011 dari http://www.linezine.com/2.1/features/cqmm wiyp.htm .

Sadiman, Arief S. 2010. Media Pendidikan:Pengertian Pengembangan dan Pemanfaatannya. Jakarta: Rajawali Press.

Sugiyono. 2010. Metode Penelitian Pendidikan Pendekatan Kuantitatif, Kualitatif, dan $R \& D$. Bandung: Penerbit Alfabeta.

Sukmadinata, Nana Syaodih. 2008. Metode Penelitian Pendidikan. Bandung: PT Remaja Rosdakarya. Supriyati, Yetti. 2007. Strategi Pembelajaran Fisika. Jakarta: Universitas Terbuka.

Tippler, Paul A. Fisika untuk Sains dan Teknik [Alih Bahasa: Lea Prasetio, Rahmad W.Adi] Edisi 3 Jilid 1. Jakarta: Penerbit Erlangga. 